\title{
Traditional Practices Used by Infertile Women in El Mansoura City.
} Amal Adel Ali, Assist .Prof. Dr. Hadayat Abd EL-Raof Amasha, Assist .Prof. Dr. Nagat Salah Shalaby, Dr., Elsayda Hamdy Nasr

* B.Sc, Mansoura University, Assist Prof. of Maternity, Gynecological and Obstetrics Nursing, Faculty of Nursing - Port Said University, Assist Prof. of Maternity, Gynecological and Obstetrics Nursing, Faculty of Nursing - Port Said University, Lecturer of Maternity, Gynecological and Obstetrics Nursing, Faculty of Nursing Port Said University.

\begin{abstract}
Background: Traditional practices are not new concepts, they have always been an integral part of all human cultures and they are transmitted from generation to generation through taboos or written documents. They constitute a major influence on the health of the individuals. The aim: This study was aimed to assess the traditional practices used by infertile women and assess the factors affecting it. Setting: The present study was carried out at gynecologic outpatient clinic and inpatient department affiliated to three governmental hospitals (El-Gamalia, Meet Salsil and El-Manzala). Study design using exploratory descriptive design on 200 infertile women. Tool: An interview schedule it entailed seven parts; Socio-demographic characteristics, medical and surgical and Reproductive history, diagnostic methods, causes of infertility and traditional practices. The results of study finding that, more than one third of infertile women used "herbal and shock" (37.0\% \& 37.5\%) respectively as a traditional practices for infertility treatment, while more than two fifths were used "belonging to another women, ritual and remedies" $(42.5 \%, 40.5 \%$ and $46.5 \%)$ respectively and only (4.5\%) used magic and Quranic verses. The most causes of using traditional methods reported by studied women were "positive previous experience, family desire, cheap and available". Conclusion: most common traditional practices used by infertile women were remedies. Recommendations: Outreach health education programs should be developed for infertile women to increase their awareness about the medical treatment of infertility and the adverse effects of harmful traditional practices on their health.
\end{abstract}

Key words: Traditional practices, infertile women, complementary treatment. 


\section{INTRODUCTION}

Infertility is a public health problem in middle and low-resource countries . It is defined as the failure to achieve a clinical pregnancy after 12 months or more with regular unprotected sexual intercourse. it an inability of a couple to achieve pregnancy for at least one year of trying to do so without using any means of birth control (Ombelet et al., 2008, World Health Organization “WHO”, 2014 \&Cooper et al., 2010).

In developing countries, where child-bearing is greatly valued, infertile couples are faced with problems ranging from overt ostracism or divorce to more subtle forms of social stigma leading to isolation and mental distress(Tabong,2013) Couples seeking infertility treatment commonly face severe strains on their emotional, social, and financial resources (Peterson et al., 2010).

There a lot of women are looking toward traditional practices for treatment of infertility; because medical treatment can be expensive and beyond astronomical for most of them, it is often painful, invasive and creates emotional mood swings, which are difficult to control (Gunay et al., 2005).

The traditional practices can be classified into practices related to herbs, previously delivered woman or another woman, magic or zaar, rituals, using Quranic verses, woman's shock and remedies (Wright $K$, 2006). They usually seek treatment for infertility from religious leaders and traditional healers, since they view it as a supernatural problem caused by evil spirits (Reproductive Health Outlook, 2006).

Certain traditional practices are not doubt useful, others are harmless and some are positively dangerous and may affect women's health. The nurse should identify these practice to be able to dispel myths and correct misbelieves surrounded them (Boon et al., 2004).

Therefore nurses must be equipped with knowledge, skills and motivations to enable them to facilitate and support infertile couples to cope with these problems without harmful practices, anxiety, depression, emotional strain, and marital complication (American Society for Reproductive Medicine “ASRM”, 2012). 
Nurse must have updated information and the latest researches. They can provide medical counseling and support for couples so, that options and decisions are not overwhelming. Nurses utilize their experience of coaching with couples through infertility journeys to bring the right word, the right nudge, the right question, the right challenge (Atri, 2011).

\section{Significance of Study:}

Significant improvement of infertility treatments has been made it possible for many infertile couples to conceive with medical assistances and give good results with most of them. However, the infertile women still use traditional practices. .In Egypt , Abdel Menem et al., (2008) found that, the infertile women used traditional practices such as ritual(49\%), herbal(20.5\%), belongs of another women(19\%), $\operatorname{shock}(17.5 \%)$ and magic $(2.5 \%)$ to treat infertility. Some of which are beneficial to all members, while others are harmful to a specific group, such as women may be harmful to their physical health or psychological health such as using placenta or dead body, snake, train ....etc., for treatment infertility among women, for that, the current study was carried to identify traditional practices used by infertile women and identify factors leading to using these traditional practices used by infertile women.

\section{AIM OF STUDY:}

The aim of the present study is to:

- Assess the traditional practices used by infertile women.

- Assess the factors leading to use these traditional practices by infertile women.

\section{Research questions:}

1. What are the traditional practices used by infertile women?

2. What are the factors leading to use these traditional practices by infertile women?

\section{SUBJECTS AND METHODS:}

\section{Technical Design:}

-Research design: Exploratory descriptive design was utilized in this study to assess the traditional practices used by infertile women.

- Setting: The present study was carried out in obstetrics and gynecological department and outpatient clinic in 3 general hospitals representing three districts at 
Mansoura city, namely: El-Gamalia hospital, Meet Salsil hospital and El-Manzala hospital.

\section{Sampling design:}

Target Population: The subjects consisted of infertile women; they were selected from the previous mentioned settings

Sample size: 200 women.

Sample type: Purposive sample was utilized to select the required sample size.

\section{Inclusion criteria:}

1- Having infertility lasting 1 year or more.

2- Infertile women primary or secondary.

3- Previous or current using of at least one of the traditional practices for treatment of infertility.

\section{Tools of data Collection:-}

Three main tools were used in the study for data collection.

A structural interview schedule was developed and utilized by the researcher to collect the necessary data from women. It entailed seven parts:

The first part, include Socio-demographic characteristics. The second part, include Medical history such as (diabetes mellitus, hypertension, heart disease, renal disease ... etc). The third part, include( surgical history such as previous surgical operation. The fourth part, consists of(a) Menstrual history such as( age of menarche, interval,....etc) (b) Reproductive health history such as (gravidity, parity, number of living children,.....etc), The fifth part, consists of diagnostic methods of infertility female and male diagnostic methods female diagnostic methods such as:(Ultrasound, Blood analysis, Hormonal assay, Swap, Hysterosalpinogram...etc).The six part, consists of data related to causes infertility, female factors and male factors such as (Ovarian cyst, obstructed fallopian tube, Idiopathic, Inflammatory disorders, Toxoplasmosis, Poly cystic, ovarian syndrome....etc), and The seven part, include data related to traditional practices used for fertility among infertility woman such as: -Nature of practice, reason for use and frequency of use. 
- Woman's belief about the effectiveness of these traditional practices.

- Factors affecting use traditional practice (positive previous experience, family pressure, cheap, available and natural. ...etc).

- Factors affecting use traditional practice (positive previous experience, family pressure, cheap, available and natural. ...etc).

\section{II- Administrative Design :}

Before starting any steps in the study, an official letter was addressed from the dean of the Faculty of Nursing to the medical directors of the identified study settings, requesting their cooperation and permission to conduct the study. In addition, an oral consent was taken from women in the study, after explaining the purpose and the importance of the research for each of them.

\section{Ethical Considerations}

The aim of the study was explained to the women to take their permission to participate in this study. The data was confidential and that was explained to the participant subjects. Professional nursing help was provided whenever needed.

\section{III-Operational design:}

This part was covered in the following phases:-

\section{Validity of tool:}

The researcher designed an opinnionnaire sheet to test the content validity of the assessment questionnaire sheet for women by a jury including 5 experts in the field of nursing; maternity, obstetrics and gynecological nursing, community and family health. It involved two parts:

1. The opinions of the experts for each item were recorded on a two-point scale: relevant, not relevant and clear, not clear.

11. General or overall opinion about the form, they were requested to express their opinions and comments on the tool and provide any suggestions for any additional or omissions of items. Then necessary modifications were done. This phase was carried out in a period of two months.

\section{Reliability:}

Confirming the stability of the questionnaire, Cronbach's alpha was used because it gives the minimum reliability coefficient scale, beside it does not require 
reapplication, and it has been shown that the Cronbach's alpha coefficient equal to 0.0829 is an excellent factor in such studies.

\section{Pilot Study:}

A pilot study was carried out on $10 \%$ from the total sample to evaluate the clarity, and applicability of the tools. Those women were excluded from the study sample.

\section{Field of work:}

Data were collected from the selecting settings by the researcher using the constructed tools. The purpose of the study was explained to the women prior to sharing in this study. The researcher attained the study setting from 9 am to $12 \mathrm{pm}$ and can be obtain two to three women on the day. Full information and way on contact was assured. Based on the inclusion and exclusion criteria (researcher asked women about her marriage and her pregnancy time if she was pregnant after one year or more or non-pregnant and use one or more traditional methods for fertility she included in study). Women were recruited in the study after obtaining oral consents.

Each woman was interviewed while attending gynecologic outpatient clinic or during her stay in gynecologic inpatient department of the previously mentioned setting, questionnaire sheet filled in about 20 minutes. Collection of data covered a period of 6 months from 1 January 2015 until the end of June 2015.

VI-Statistical Analysis: Statistical analysis was done using (SPSS 11.0) statistical software packages. Data were presented using descriptive statistics in the form of frequencies and percentages for qualitative variables, and means and standard deviations for quantitative variables. Qualitative variables were compared using chisquare test. The collected data were organized, categorized, tabulated and analyzed by using the computer. Data entry was done using Epi-info computer software package, while statistical analysis was done using stat graphic, statistical software package, quality control was done at the stages of coding and data entry. Univariate analyses including: McNemar- test and Fisher's exact test were used to test the significance of results of qualitative variables. 


\section{RESULTS:-}

Table (1): describes socio-demographic characteristics of studied women. reveals that, more than two fifth of studied women (42.0\%) aged between 20-25 years old, while (65.0\%) Women's age at marriage less than 20 years old. Regarding educational level about half of studied women $(46.0 \%)$ have secondary level of education, while only $(2.0 \%)$ of them were illiterate. The majority of studied women $(81.0 \%)$ were housewives. Also monthly income more than three fifth $(60.5 \%)$ of them hadn't enough monthly income. Concerning the residence of studied women, nearly three quarters $(72.0 \%)$ of them resident at rural area and the majority (90.0\%) of husband of studied women always present. The same table also shows that, the duration of marriage most of studied women $(70.0 \%)$ were had from 1 to 5 years duration. in relation to the period of infertility, the majority of studied women $(90.5 \%)$ were from 1-5 years period.

Figure (1): shows the distribution of women according to types of their traditional practices used by infertile women; more than one third of infertile women were used herbal and shock $(37.0 \%, 37.5 \%)$ respectively as a traditional practices for infertility treatment, while more than two fifths were used belonging to another women, ritual and remedies $(42.5 \%, 40.5 \%$ and $46.5 \%)$ respectively, however only $(4.5 \%)$ of them were used magic.

Figure (2): illustrates the factors leading to use traditional practices; the most causes of using traditional practices reported by women were, positive previous experience, family desire, cheap and available. 
Table (1): Distribution of studied women according to their Socio-demographic characteristics $(n=200)$.

\begin{tabular}{|c|c|c|}
\hline Variable data & No. & $\%$ \\
\hline \multicolumn{3}{|l|}{ Women age (years) } \\
\hline$<20$ & 57 & 28.5 \\
\hline $20-25$ & 85 & 42.5 \\
\hline $26-30$ & 42 & 21.0 \\
\hline $31-35$ & 14 & 7.0 \\
\hline$>35$ & 2 & 1.0 \\
\hline Min - Max & \multicolumn{2}{|c|}{$15-36$} \\
\hline Mean \pm SD & \multicolumn{2}{|c|}{$23.0 \pm 5.11$} \\
\hline \multicolumn{3}{|l|}{ Women's age at marriage (years) } \\
\hline$<20$ & 130 & 65.0 \\
\hline $20-25$ & 63 & 31.5 \\
\hline$>25$ & 7 & 3.5 \\
\hline Min - Max & \multicolumn{2}{|c|}{$13-31$} \\
\hline Mean \pm SD & \multicolumn{2}{|c|}{$18.36 \pm 3.69$} \\
\hline Women educational level & & \\
\hline Illiterate & 4 & 2.0 \\
\hline Read and write & 61 & 30.5 \\
\hline Secondary & 92 & 46.0 \\
\hline University or above & 43 & 21.5 \\
\hline \multicolumn{3}{|l|}{ Women occupation } \\
\hline Working & 38 & 19.0 \\
\hline Housewife & 162 & 81.0 \\
\hline \multicolumn{3}{|l|}{ Income } \\
\hline Enough & 74 & 37.0 \\
\hline Not enough & 121 & 60.5 \\
\hline More than enough & 5 & 2.5 \\
\hline \multicolumn{3}{|l|}{ Residence } \\
\hline Urban & 56 & 28.0 \\
\hline Rural & 144 & 72.0 \\
\hline \multicolumn{3}{|l|}{ The presence of husband } \\
\hline Short time travel & 20 & 10.0 \\
\hline Always present & 180 & 90.0 \\
\hline \multicolumn{3}{|l|}{ Period of marriage (years) } \\
\hline $1-5$ & 140 & 70.0 \\
\hline $6-10$ & 54 & 27.0 \\
\hline$>10$ & 6 & 3.0 \\
\hline Min - Max & \multicolumn{2}{|c|}{$1-16$} \\
\hline Mean \pm SD & \multicolumn{2}{|c|}{$4.66 \pm 2.63$} \\
\hline \multicolumn{3}{|l|}{ Period of infertility (years) } \\
\hline $1-5$ & 181 & 90.5 \\
\hline $6-10$ & 18 & 9.0 \\
\hline$>10$ & 1 & 0.5 \\
\hline Min - Max & \multicolumn{2}{|c|}{$1-15$} \\
\hline Mean \pm SD & \multicolumn{2}{|c|}{$2.90 \pm 2.17$} \\
\hline
\end{tabular}




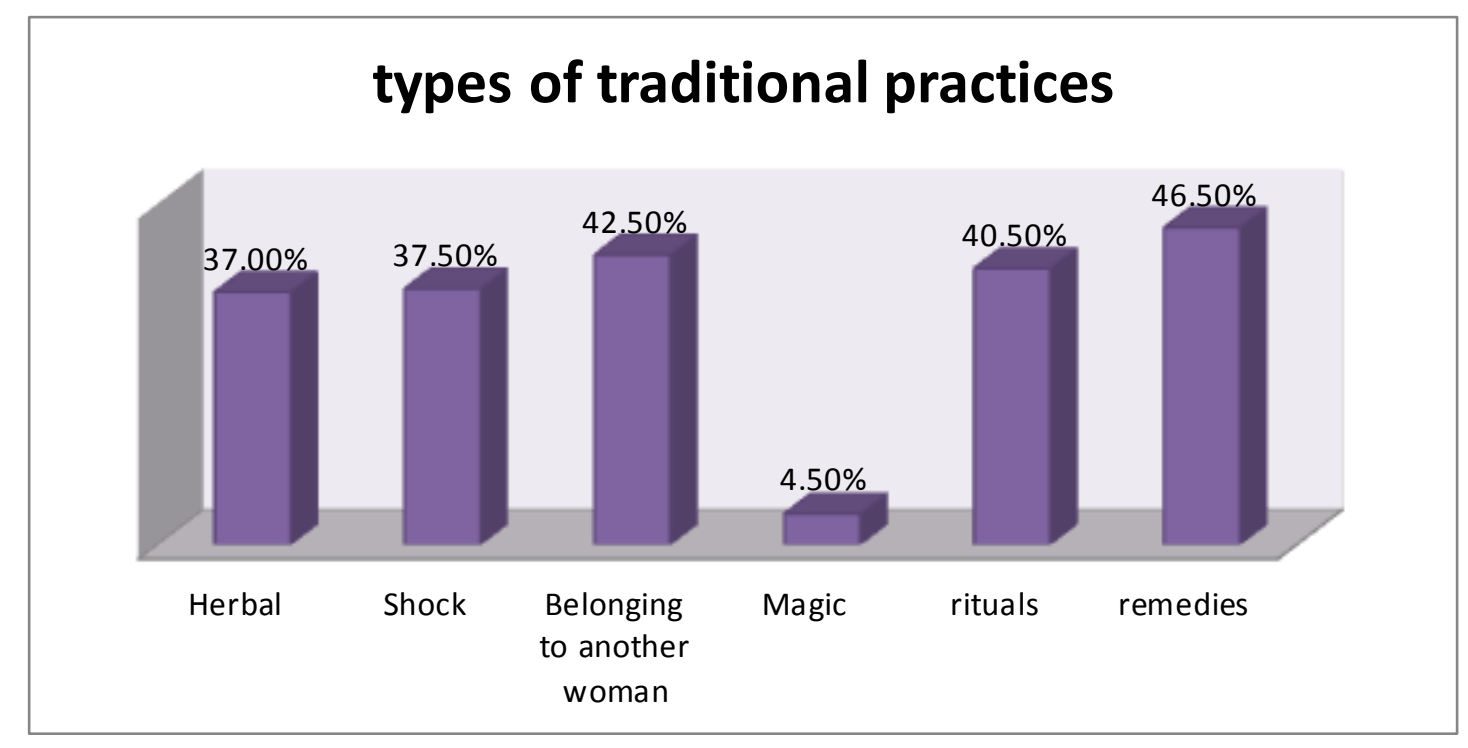

Figure (1): distribution of women according to types of their traditional practices

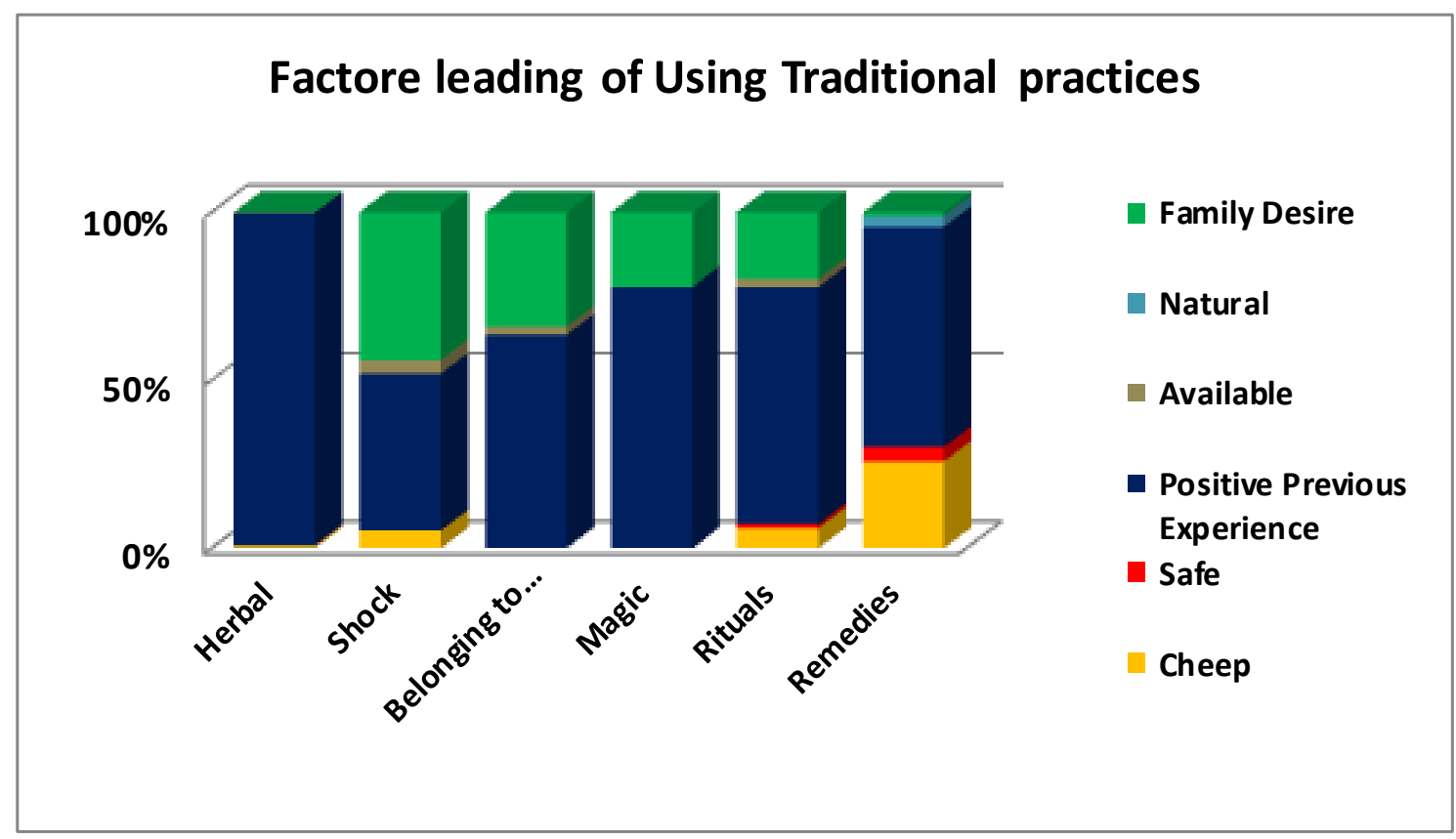

Figure (2): Factors leading to using traditional practices.

\section{DISCUSSION:}

Recently in an American study by Berkley (Treating infertility with herbal medications) stated that, herbal supplements are helpful in supporting fertility for both 
women and men. For women, vitex (chaste berry), red clover used to help restore hormonal balance are combined with the same vitamins and minerals found in a prenatal vitamin (Berkley, 2015). Also, Khalid, (2007) stated that, using denker in the form of tablets for 3 months resulted in $60 \%$ success rate of treatment of infertility. This result is consistent with the finding of the current study, which there was more than one third of studied women were used herbal with $59.5 \%$ success rate to treat infertility as denker, fenugreek, cinnamon, and red clover.

This finding partly similar to Abdel Menem et al., (2008) who found that, the infertile women used herbal to treat infertility as pepper, henna, wormwood (sheeh), denkar, black seeds, fenugreek, and carnation. This is may be due to the women used herbal because it is natural, available and not costly methods.

The current study finding showed that, there was more than one third of studied women used shock for treating infertility. It was noticed that, women used dead snack, dead's abrasive sponge and entering cemetery. The results are almost the same as those by Abdel Menem et al., (2008) and El-Medany, (1983) who found that, some infertile women used shock to treat their infertility such as entering a grave to see a dead person or using his / her fiber to take a bath and throwing her by a plastic snake. In addition, it is in agreement with Nazik et al., (2015) who reported that, infertile women were visiting tombs or burial places as a traditional method to treat infertility.

The current study revealed that, studied women were used belongs of another women to be pregnant such as; placenta and weaning milk. They were used it per vagina (blood of placenta or breast milk), sitting on placenta and walking across. This finding is partly similar with Abdel Menem et al., (2008); El-Medany (1983) who reported that, some women were treating infertility by sitting on the placenta or inserting a cotton sponge soaked with lochia discharge or breast milk into the vagina, putting the abortus in water and taking bath over it so abortus gives the symbol of death, while water used during taking bath gives the symbol of returning to life. This is may be due to, the women were used belongs of another women because they believed that, if they used this method, they will become fertile as them. 
Jordan (2005); El-Masry (2002); Baasher et al., (1982) stated that, in many cases in Sudan the women used of the Quran verses are written on a piece of paper and made in the form of an amulet (higab = guarder) for the woman to wear it as along bracelet or around the forearm to appease the evil spirit and help her get pregnant. In addition, verses of the Quran are written on a special wooden board (loah) with a special ink (amar) and then washed with water. This water (mihaya) is given to be drunk in doses. The above result of this study is consistent with the present study results; which it revealed that, the minority of studied women were used magic and Quranic verses to treat infertility by wearing blue beads and using fumes to get rid of evil and spirits (Zaar) or visited sheikhs to take a Higab.

This finding also similar with the results of a study done by Abdel Menem et al., (2008) in Kafer El-dawar city, who found that, a minority (only 4.5\%) of studied women also used Quranic verses. For example, a written amulet (Higab) was taken from a sheikh, wearing blue beads and using fumes to get rid of evil and spirits. This finding may be explained by, infertility can trigger a crisis of faith for any Muslim; these feelings are normal. Seeking spiritual guidance from their faith leader is essential to help them cope with the impact of infertility and its treatment.

In the present study, the participating women used rituals to treat infertility, women used Mushahara necklace, slaughter peagon on the head and Altar. Mushahra or Kabsa was the cause of infertility as reported by women in the present study. This finding is in the same line with (Inhorn, 2005) who found that, female infertility is often attributed to Kabsa among the urban and rural poor women in Egypt.

Inhorn, (2005) added that, "Mushahara or Kabsa is a form of boundary crossing by symbolically polluted individuals into the rooms of reproductively vulnerable women". When Kabsa occurs, it causes the binding of women's reproductive bodies, threatening their fertility, their husband's virile procreativity, and ultimately, the social reproduction of Egyptian society at large. Because Kabsa is viewed as the leading cause of female infertility, an extremely socially stigmatizing condition in Egypt is greatly feared by women. 
This ritual were done by studied women putting mushahara necklace in water, moving it and walking over it seven times, then taking bath with this water. This finding is similar to the finding of Abdel Menem et al., (2008). It is also nearly similar to Baasher et al., (1982) who reported that, in Sudan; red beads are included in the mushahara necklace to prevent and treat infertility.

Another method of rituals, which was done by studied women in the current study, was visiting some sheikhs and mosques to offer some vows (nazr). It is also partly similar to Gunay et al., (2005); Abdel Menem et al., (2008) who reported that, the more prevalent traditional methods were visiting mausoleums, where religious leaders are buried, having an amulet written and giving "gifts" or "sacrificing animals".

Giwa-Osagie, (2007) added that, sacrifices of "poultry", goats or rams may also be performed to the gods/goddesses that may be annoyed or to invite their favor so that pregnancy may occurs. Gifts or sacrifices may also be made to ancestral spirits while followers of various religions, including Christians, often fast, apply anointed oil to their bodies or drink what they describe as "holy water" to hasten pregnancy.

This is similar to Dyer, (2008) who found in his study in Nigeria that, infertility treatment involves sacrifices offered to deities or ancestors, various ceremonies to lift evil curses. And also, agrees with (Leonard, 2002) who found in Southern Chad, interventions of infertility involve reconciliation ceremonies, food offerings and ritual cleansing.

In the Gambia, Sundby, (2003) found that, interventions of infertility were usually based on medicinal drinks and amulets containing writings from the Quran. Other aspects of traditional health care involved of spiritual healers, herbalists, fortunetellers and visits to sacred places, in addition, reconciliation ceremonies, food offerings and ritual cleansing. Several other studies described the important role that herbs, medicinal drinks, amulets, cleansing rituals, spiritual and religious healers played a role in the management of infertility in Africa (Seybold, 2002). Naziket et al., (2015) reported that, $26.7 \%$ \& $11.4 \%$ of infertile women using specifically written amulets and vowing respectively to make an offering. 
The results of the current study indicate that, studied women used shock, magic, and liturgies methods. This is may be due to, infertile women are under pressure from their spouses, families, environment and the society and this pressure leaves them open to the application of all kinds of different methods. From these results, it is also obvious that, cultural and traditional factors are still prevalent.

The current study finding, studied women used therapeutics to treat infertility such as; cranial osteopathy closed-open back (rubbed with olive oil and cupping) and acupuncture. This finding similar with Smith, (2010) who reported that, the women under the study were using massage, acupressure, and acupuncture for treatment of infertility. Also, Fertility New Zealand, (2013) stated that, women with histories of pelvic pain, especially associated around menstruation, back pain, head, neck or back injury should seek to resolve these issues before pregnancy with a registered osteopathy.

This finding disagrees with study conducted by Heim, (2007) to assess the effectiveness of osteopathic treatment on the hormone level of hyper androgen emic women, he found that, osteopathy was non-effective treatment of infertility.

At the same line Gaware et al., (2009) stated that, aromatherapy (oil massage, oil burner, and bath), and acupuncture were helpful in treatment of infertility; and Campbell, (2015) stated that, aromatherapy increasing fertility. Moreover, acupuncture was regulating the hormones levels, the menstrual cycle, stimulating ovulation and fertile mucous, increasing the blood flow to the uterus, improving uterine lining, lowering stress hormones thus inducing relaxation, reducing the hostile mucous, alleviating pain, improving the sperm count, motility, and abnormal forms (Fertility New Zealand, 2013).

In addition, placing suction cups on the women's back is a form of traditional remedies used by some studied women in the present study to treat infertility. This finding is in line with the findings of both Osman, (2006) and Abdel Menem et al., (2008). This was explained by Jordan, (2005) who stated that, a healer rubbed a woman's pelvis with olive oil and placed suction cups on her back to close her opened back, which was believed to be a cause of infertility. This is may be due to, infertile 
couples experienced some stress and stress has a direct effect on hormonal balance, all stress conditions can be seen as unhelpful to fertility. Therefore, the previous mentioned therapeutic practices may be helpful in treatment of infertility as it relieve stress.

Regarding the factors leading to the use of traditional practices by the women under the present study reported they were practicing it because the traditional practices had "positive previous experience, family desire, cheap, safe, available and failure of medical treatment. This finding is comparable with Vincent et al., (1996) who stated that, infertile couple were using traditional practices as it being lower cost, safer and more effective.

At the same time, Tabong et al., (2013) found that, child-bearing is greatly valued, infertile couples were faced of social stigma leading to isolation and mental distress. In addition, married couples were under enormous pressure to procreate. Also, (Ombelet et al., 2008) found that, having children is an essential part of life while infertility is seen in much of Sub-Saharan Africa (SSA) as a personal tragedy, with the potential to impact the entire family or community.

This finding disagrees with (Rayner et al., 2009) who reported that, biomedical practitioners are often consulted later when religious and traditional practices have failed to provide a solution to the infertility problem. Also, Kaadaaga, (2014) found a higher prevalence of herbal medicine used by women who were married and those who had never conceived. However, women who were less than 30 years of age and those who were less educated they were less likely to use herbal medicines. Educated women were more likely to have some income that they used to pay for herbal medical treatment. Several studies showed that, older women, who were better educated and employed with high income, they were more likely to use traditional practices.

Also, Addo, (2007) in Ghana found that, under privileged women attending the gynecological clinic were more likely to utilize herbal medications in the management of their infertility. Van Balen, (1997) found that, the reasons for using traditional practices were increasing the chances of having child, failure of standard of fertility treatments, and desire to avoid standard medical fertility treatment. 


\section{CONCLUSION:}

Based on study findings, it can be concluded that: The traditional practices used by infertile women were herbal, shock, belonging to another women, ritual, remedies and magic. The most common traditional practices used by infertile women were remedies; they included cranial osteopathy, closed-open back (Cupping) and acupuncture. The majority of infertile women believed that traditional methods could be effective in treating infertility, especially when some of them became pregnant after using these methods. The factors that lead to use traditional methods were positive previous experience, family pressure be side cheap and available.

\section{RECOMMENDATIONS:}

Based on the results of the present study, the following recommendations were suggested:

- Educational programs should be carried out for nurses to provide them with essential information regarding infertility and traditional practices used to treatment infertility to provide awareness for infertile women about effect of harmful traditional practices.

- Women's access to family planning and infertility clinics should be improved to reduce the risk of using traditional practices to treat infertility.

- The attitude and communication skills of health workers should be improved to help infertile women seek medical advice.

- Encourage research concerning the traditions and beliefs of the community to find out the possible complications and health problems that are resulted from using traditional practices to treat infertility.

- Evaluate the effect of teaching programs for infertile women to counteract their use of traditional practices.

\section{Corresponding author}

Amal Adel Ali ,B.Sc. Nursing, Faculty of Nursing, Mansoura University

Amaml_adel26@yahoo.com_ Mobile 01013204443 


\section{REFERENCES:}

Abdelmenem, A.H., Sobhy, S.I., \& Shoeib, F.N., (2008): Traditional practices for treatment of infertility among rural women.

Addo, V., (2007): Herbal medicines: socio-demographic characteristics and pattern of use by patients in a tertiary obstetrics and gynaecology unit. J Scio Technology (Ghana) 2007, 27(3):149-155.

Al-Masry, H. El., (2002): Folklore and construction of class .Study operations produce popular culture and circulation among the poor Greens in Cairo Master thesis in Sociology .Faculty of Arts, Cairo University, PP; 6- 272.

American Society for Reproductive Medicine, (ASRM). (2012): Preparing for IVF: Emotional considerations: Available at: http://www.asrm.org/detail.aspx?id=1902.

Atri, S., (2011): Role of nurse in In vitro Fertilization. The Nursing Journal of India; Cll (4). Available at: http:// www.tnaionline.org/ thenursing_apr11.htm.

Baasher, T., Bannerman, R., Rushwan, H., \& Sharaf, I., (1982): Background papers to the World Health Organization: traditional practices affecting the health of women and children. WHO/EMRO Technical Publication: Alexandria, 1982; 2: 35-40.

Berkley, M., (2015): Treating infertility with herbal medications. American Pregnancy Association. Retrieved htom: americanpregnancy.org/infertility/herbs/.

Boon, H., Verhoef, M., O'Hara, D., Findlay, B., Majid, N., (2004): Integrative Health Care: Arriving at a Working Definition. Alternative Therapies in Health and Medicine. 10(5):48-56

Campbell, L., (2015): Increasing fertility through the use of essential oils. The Natural Fertility Company. Retrieved from: http://natural-fertility-info.com/fertilityessential-oils.html. 
Cooper, T.G., Noonan, E., Von Eckardstein, S., (2010): "World Health Organization reference values for human semen characteristics". Hum. Reprod. Update 16 (3): 231-45.

Dyer, S.J., (2008): Infertility-related reproductive health knowledge and help-seeking behaviour in African countries. Hum Reproductive 2008, 1:29-33.

Elmadany, M.A., (1983): Popular Tags in the field of infertility in women doctorate thesis in psychiatry medicine, Faculty of medicine Alazahr University: PP; 166240,83-9.

Fertility New Zealand, (2013): Natural fertility treatment. Retrieved from: http://www.fertilitynz.org.nz/files/2313/8975/0640/1213_Natural_fertility_web.pdf

Gaware, V. M., Parjane, S. K., Merekar-Abhijit, N., Pattan, S. R., Dighe, N. S., Kuchekar, B. S., \& Godge-Rahul, K., (2009): Female infertility and its treatment by alternative medicine: A review. Journal of Chemical and Pharmaceutical Research; 1(1):148-162.

Giwa-Osagie, O., (2007): Social and ethical aspects of assisted conception in Anglophone Sub Saharan Africa. Available at URL: http://www.who.int/ reproductive-health/ infertility 19-pdf. Last accessed on: 30 September 2007

Heim, S., (2007): Does osteopathic treatment influence the hormone level of hyper androgen emic infertile women? Retrieved from: http://www.osteopathicresearch.com/paper_pdf/HeimSabine1.pdf.

Inhorn, (2005): Kabsa (a.k.a. Mushahra) and threatened fertility in Egypt. Soc Sci Med 2005 Aug; 39(4): 487-505.

Jordan, (2005): Health and welfare .U.S. Library of Congress.(2003): Available at URL: http://countrystudies. US /Jordan /44.htm. Last accessed on: 1 May 2005

Kaadaaga, H.F., Ajeani, J., Ononge, S., Alele, P.E., Nakasujja, N., Manabe, Y.C., \& Kakaire, O. (2014): Prevalence and factors associated with use of herbal 
medicine among women attending an infertility clinic in Uganda. BMC Complement Altern Med; 14: 27. doi: 10.1186/1472-6882-14-27.

Khaled, A., (2007): Infertility: herbs and dagals. Available at URL: http: II forum. Amr khaled. net/showthread .php t $=4191 \&$ page 8 Last accessed on 7 January 2007.

Leonard, L., (2002): 'Looking for children': the search for fertility among the Sara of southern Chad. Med Anthropol 2002;21:79-112.

Nazik, E., Apay, S., Özdemir, F., \& Nazik, H., (2015): Traditional Practices of Turkish infertile women: an example from a rural county. Coll Antropol; 39(1): 2125 .

Ombelet, W., Cooke, I., Dyer, S., Serour, G., Devroey, P., (2008): Infertility and the provision of infertility medical services in developing countries. Hum Reprod Update 2008, 14(6):605-621.

Osman, M., (2006): Osman Gynecology. Alexandria: Alexandria University, 2006; $106-26$.

Peterson, B.D., Pirritano, M., Block, J.M., \& Schmidt L. (2011): Marital benefit and coping strategies in men and women undergoing unsuccessful fertility treatments over a 5-year period. FertSteril; 95:1759-1763 e1.

Rayner, J.A., McLachlan, H.L., Forster, D.A., \& Cramer, R., (2009): Australian women use of complementary and alternative medicines to enhance fertility: exploring the experiences of women and practitioners .BMC Complement Alternative Med 2009, 9:52Dyer SJ,

Reproductive health outlook, (2006): infertility. Available at URL :http://www.rho.org/htm/infertility _overview.htm. Last accessed on: 1 November 2006.

Seybold, D., (2002): Choosing therapies: a Senegalese woman's experience with infertility. Health Care Women Int 2002;23:540-549. 
Smith, J.F., Eisenberg, M.L., Millstein, S.G., Nachtigall, R.D., Shindel, A.W., Wing, H., Cedars, M., Pasch, L., \& Katz, P. P., (2010): The use of complementary and alternative fertility treatment in couples seeking fertility care: data from a prospective cohort in the United States. Fertil Steril. 2010; 93(7):2169-2174. doi: 10.1016/ j.fertnstert.2010.02.054.

Sundby, J., (2003): Infertility in the Gambia: traditional and modern health care. Patient Educ Couns 2003 31:29-37.

Tabong, P.T.N., Adongo, P. B., (2013): Understanding the social meaning of infertility and childbearing: a qualitative study of the perception of childbearing and childlessness in Northern Ghana. PLoS One 2013, 8(1):e 54429.

VanBalen, F., Verdurmen, J., Ketting, E., (2001): Choices and motivations of infertile couples. Patient Educ Couns 2001, 31:19-27.

Vincent, C., Furnham, A., (1996): why do patients turn to complementary medicine? An empirical study. Br J clinpsychol 1996; 35(pt 1):37-48.

World Health Organization (WHO), (2014): Sexual and reproductive health, infertility definitions and terminology. Available at: http:// www.who.int/reproductivehealth/topics/infertility/definitions/e/.

Wright, K., (2006): Defining Infertility. Network 2003; 23(2). Available at URL:http://www.fhi.org/en/RH/pubs/Network/v23_2/nt2321.htm.Last accessed on: 1 November 2006. 


\section{الـممارسـات التـقليـليـة التي تستخدم بين السيدات الـغير قــادرات علـى الإتجـاب في}

\section{مسلينـة المـنصورة}

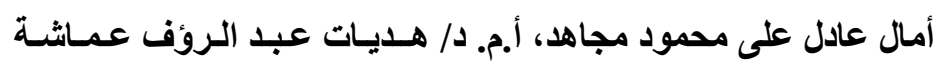

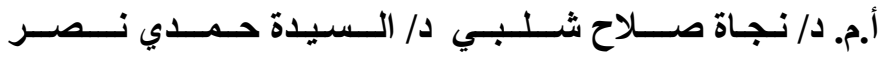

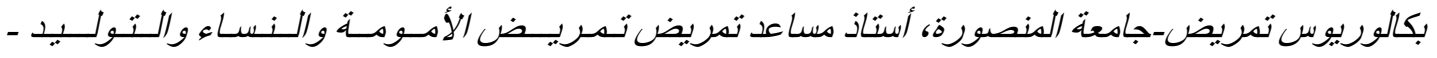

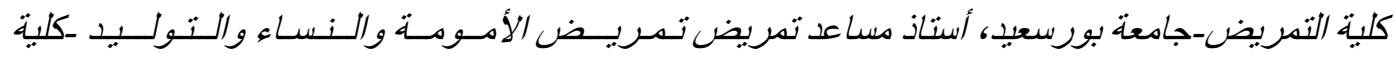
التنريض-جامعة بورسعيد ، مدرس تمريض الأمومة و النساء والتوليد- كلية التصريض- جامعة بورسعيد

\section{الخلاصة}

الممارسات التقليدية ليست مفاهيم جديدة ولكنها جزءا لا يتجزأ من جميع الثقافات البشرية وانتقلت من جيل إلى جيل. وبعض هذه الممارسات مفيدة بلا شك وبعضها غير ضار والبعض الأخر ضار جدا. تهدف هذه الدراسة الوصفية إلى معرفة الممارسات التقليدية التي تستخدم بين السيدات الغير قادرات على الانجاب و العوامل المؤثرة عليهاوأجريت هذه الدراسة الوصفية في المستشفيات العامه (الجمالية ، ميت سلسيل ، المنزلة ) علي عينة مستهدفه قو امها 200 سيدة لديها عقم واستخدمت استمارة استبيان لجمع المعلومات عن الممارسات التقليدية التي استخدمنها السيدة لعلاج العقم. وقد أظهرت نتائج الدراسة، أن الممارسات التقليدية التى استخدمت بواسطة السيدات لعلاج العقم اكثر من ثلث العينة استخدمن الاعثاب والخضة بينما اكثر من خمسين العينة استخدمن الطقوس و4.5 \% فقط استخدمن السحر والآيات القرانية و سبب استخدام السيدات لهذة الممارسات التقليدية: الخبرة السابقة ،رغبة الاسرة ، قلة التكلفة ومتاحة. وقد استنتجت الدر اسة الحالية ان الغالبية العظمى من السيدات استخدمن العلاج التقليدى ويثمل (المجبر اتى ،الكئوس والابر الصينية). وبناءا عليه أوصت هذه الدراسة وجوب الته عمل بر امج تثقيف صحي تصل الى السيدات الغير قادرات على الانجاب لتو عيتهن بآهمية العلاج الطبى و التأثثر العكسى للممارسات التقليدية الضارة على صحتهن. الكلمات المرشدة : المعارسات التقلبية ، العقم ، العلاج البديل في العقم . 